\title{
A Study on Problems Faced By Exporters of Gems and Jewellery Industry
}

\author{
${ }^{1}$ Dr. Parul Agarwal, ${ }^{2}$ Ms. Richa Devgun, ${ }^{3}$ Dr. J.S. Bhatnagar \\ ${ }^{I}$ (Dean \& Director, School of Management, JECRC University, Jaipur India) \\ ${ }_{2}^{2}$ (Research Scholar, Department of Management, JECRC University, Jaipur India) \\ ${ }^{3}$ (Principle of Government College, Merta City India)
}

\begin{abstract}
Gems and jewellery are part of many cultures and customs around the world. Gems and jewellery have been important part for both aesthetic as well as investment purposes. Gems and jewellery industry has gradually become important for the Indian economy due to its contribution in India's total exports. This sector accounts about 14.98\% of the country's total merchandise exports estimated at US\$262290.13 million in 2015 16. In last four years export of gems and jewellery decreased by $12 \%$ and exports got affected by the rising cost of raw materials, depressed demand and slowdown of markets. There are many problems faced by the exporters of gems and jewellery industry. This paper discuss the status of the exports of Indian gems and jewellery industry. Also, an attempt is made to identify the problems faced by the exporters, by reviewing various literatures and highlighted some suggestions to overcoming these hurdles.
\end{abstract}

Key Words: Export, Exporters, Gems, Import, Jewellery, Problems

\section{Introduction}

Gems and jewellery forms an important part of many cultures around the world. Gems and Jewellery have an essential place in the Indian society and economy ever since civilization emerged on the Indian soil. Jewellery, is accounted for about 50 per cent of the total luxury products sold in the country. India is renowned for handmade jewellery and was one of the first countries to start making fine jewellery from minerals and metals. Gems and jewellery industry generates large scale employment, foreign exchange earnings through exports and value addition [1]. Out of India's total merchandise exports, around $14 \%$ accounted for gems and jewellery in the financial year 2011-12. The demand in India can be segmented into consumption and investment. Investment demand for gold is important in India its accounts for about 45 percent of total market demand. Around 57 percent of the investment demand comes from coins and bars, while the rest comes from jewellery [2].

The import of gold per year in India and China worth billions of dollars which accounts for $49 \%$ of consumption of gold worldwide. In 2011 total consumption was 4067 tonnes in volume and 205.5 billion dollars in value, out of which 55\% was exclusively for gold jewellery. As a matter of fact 933.4 tonnes of gold was consumed in 2011 in India of which 500 tonnes were for gold jewellery, Inspite of the weakening of rupee compared of dollar in the second half of the year. The demand in China, the world's second largest consumer of gold (769.8 tons), increased this year by $20 \%$ [3]. Approximately 2400 metric tonnes of gold production has been done over the past five years. Mainly African countries account for major volume around $20 \%$ of that volume (480MT) [4].

Russia, Botswana and South Africa are the quality producer of diamonds in the world and for industrial diamond Australia being a major producer. De Beers is the largest diamond miner in the world [5]. Countries like India, Italy, China, Thailand and USA dominates the jewellery manufacturing in the global market which is over $\$ 100$ billion [6]. Hong Kong is famous for its craftsmanship and skill labour in jewellery set with precious stones, in particular jewellery mounted with diamond in $14 \mathrm{~K}$ and $18 \mathrm{~K}$ gold. Multi-faceted cut diamond rings combined with assorted colour precious stones are most popular around the world [7]. At present Indian gems and jewellery sector is unorganised with local players constituting about 80 percent of the overall market. Consumer preferences in designs, quality, and material across different regions have historically presented a challenge for national and organized players to create design-led differentiation.

Demand for consumption and investment is affected by several challenges. While challenges in talent and skill development, research and technology adoption, and limited financing options are core to players catering to the consumption demand for jewellery, an increasing investment demand with limited supply infrastructure affects the investment side of the market. High import dependence and regulatory curbs impact both consumption and investment demand of the market [8]. Hence the paper discussed the status of the exports of Indian gems and jewellery industry. Also, an attempt is made to identify the problems faced by the exporters, by reviewing various literatures and provide some suggestions for overcoming these hurdles. 


\section{Gems And Jewellery Industry In India}

Gems and jewellery's prime function is to decorate and adorn. The gems and jewellery industry contains sourcing, processing, manufacturing and selling of precious metals and gemstones such as Gold, Silver, Diamond, Diamond, Ruby, Sapphire, among others. Demand for different types of gems and jewellery is influenced by several factors including buyer preferences, varieties, unit values, properties, application, etc. [9]. In 1966-67 exports was $\$ 28$ million but after the establishment of gems and jewellery export promotion council, exports grows from $\$ 28$ million to $\$ 42.8$ billion in 2011-12. The size of the Indian gems and jewellery market is expected to be US\$ 43 Billion by the end of 2017 on the basis of increasing domestic demand. The country is one of the largest exporters of gems and jewellery [5].

Indian craftsmanship and variety is recognised worldwide. It is labour intensive and involves not just workmanship but a lot of patience and dedication to the art of jewellery making. The industry employs about 4.6 million persons directly and employment is expected to double in the next 10 years [10]. In the financial year 2011-2012, it accounted for 14\% of India's total merchandise exports. India has established itself as the world's largest manufacturing sector for cut and polished diamonds, contributing nearly $80 \%$ in terms of volume and $60 \%$ of the world's supply in terms of value. India is accounted for 800 tonnes gold consumption annually of which approx. 600 tonnes is used for jewellery making [11].

India is the major polishing and cutting hub for diamonds. India is the third largest consumer of polished diamonds. The diamond processing industry has spread from the State of Gujarat, which accounts for almost 85 per cent of the diamonds processed in India as compared to other states. Surat, Bhavnagar and Ahmadabad are the prominent diamond centres in Gujarat. Many diamond processing units have also been set up in Mumbai in Maharashtra. There are also diamond processing units in Trichur in Kerala, Coimbatore in Tamil Nadu, Jaipur in Rajasthan and also in Goa [12]. The high pace of urbanization and rapidly growing middle class income group in India has led Indian consumerism to new heights, particularly in the growth of the diamond jewellery sector. About 91.67 per cent diamonds sold around the world are processed in India regardless of the place they are mined [13]. UAE, US, Russia, Singapore, Hong Kong, Latin America and China are the biggest importers of Indian jewellery [14].

The Gems \& Jewellery Export Promotion Council in association with the world's crafts council has been playing a significant role in the development of the industry. Scattered efforts of individual exporters has been coordinated into a powerful engine driving the country's export led growth [15]. Government, recognizing the inherent strengths of this sector in terms of its employability potential has taken major initiatives to strengthen institutional linkages. Enhancing the skill levels of the workers commensurate with the requirement of the industry. The Government is also encouraging global partnerships and collaborative ventures for adopting a diversified approach in the jewellery sector [16].

\section{India's Position on the Global Front}

On the basis of its talented craftsmen, its superior practices in cutting and polishing fine diamonds and precious stones, and its cost-efficiencies, the gems and jewellery industry has gained global status [17]. The industry has grown at an average Compounded Annual Growth Rate (CAGR) of 5.2\% since 2000. In 2005 global gems and jewellery industry size was around US\$ 146 billion, and in 2008 around US \$ 170 billion in sales. The eight main world markets are India, USA, China, Japan, UK, Middle East, Turkey and Italy [18].

Over the last few years the market for gems and jewellery has shown steady growth worldwide except during the global economic recession in 2011-2012. India accounts for almost 50\% of the supply in international market, with its gold jewellery, cut and polished diamonds, pearls, coloured gemstones, non-gold jewellery and fashion jewellery. The Gems and Jewellery industry of India contributes nearly $55 \%$ of the world's net exports of cut and polished diamonds in value, $90 \%$ in terms of pieces and $80 \%$ in terms of carats. Out of 12 diamonds sold globally, 11 diamonds are processed in India, irrespective of where these are mined [19]. India has been the dominant polished diamond exporter representing major share of Gems and Jewellery exports of 54 per cent in 2011-12. The share of polished diamond in India's total merchandise exports stood at 8 per cent in 2011- 12 [20].

Globally, jewellery demand was up by $37 \%$ in the quarter ending September 2013 to 576 tonnes from 421 tonnes in the same quarter of 2012, reaching its highest level since Q3 2008. In China, demand was up by $54 \%$ compared to a year ago; while in India demand increased by $51 \%$. There was also uplift in demand for gold jewellery in other parts of the world: the Middle East region was up by 33\%, and in Turkey, demand grew by $38 \%$.

India and China holds the largest jewellery market in the world with more than half of the share being contributed by them alone. India and China are the two major gold consumers in the world followed by the Middle East region. In Asia Pacific other countries like Vietnam and Thailand are also large consumers of gold and thereby driving the regional growth of the market. India and China together account for almost $50 \%$ of total bar and coin demand of the world and around $60 \%$ of jewellery demand [21]. 
A study on problems faced by exporters of gems and jewellery industry

\subsection{Import}

\section{Import And Export of Gems And Jewellery}

The import of raw materials for gems and jewellery has special place in this industry. In India 90 per cent of raw material is imported. The raw material is processed and manufactured into saleable items for global market. In year 2012-13 total import was US\$ 37551 million (fig. 1) showed a decrease of $12.1 \%$ as compared to 2011-12. India was key importer of cut and polished diamond in 2011-12. India meets its entire gold demand through purchases overseas. Gold is the second-largest imported item after crude oil. The government had imposed measures to curb gold imports to contain the current account deficit, which amplified to a record in 2012-13 [22]. Gold jewellery import declined 93 per cent in the first eight months of the current financial year (2013-2014), following the government's decision to curb import of the yellow metal. Gold bar import fell slightly in 2014-15 to Rs.32, 963 crore, as compared to Rs.33, 650 crore in the previous year 2013-14. In case of rough coloured gemstone, import increased to Rs. 1740 crore in 2014-2015 from Rs. 1445 crore in 2013-14.

The government has hiked import duty on gold thrice to 10 percent, banned inward shipments of gold coins and medallions and made it mandatory for importers to export 20 per cent of their shipments before purchasing more of the metal from overseas [23]. However, after the imposition of the duty, imports of cut and polished diamonds dipped $80 \%$ from Rs.14, 472 crore to Rs. 2771 crore in last five years. Total import also decreased by $22 \%$ in 2015-16 as compared to last year [24].

\subsection{Exports}

Global gems and jewellery industry is on the way to huge transformation. India has many natural advantages to emerge as Gems \& Jewellery hub of the world. A prime portion of rough, uncut diamonds is processed in India in the form of either polished diamonds or finished diamond jewellery and then exported [19]. The record of exports of gems and jewellery from India during the year 2008-09 was 24894 million, in year 2009-2010 was US\$ 29442 million, during year 2010-2011 was US\$ 43048 million, so in year 2012- 2013 amounted to US\$ 39137 million as compared to US\$ 43211.19 million achieved in 2011-2012; indicating a decrease of 9.43\% (fig 2). [25]. Economic uncertainty, government regulations and fluctuation in the exchange rate and imposition of $2 \%$ import duty on cut and polished diamond resulted in the decline of country's gems and jewellery exports. Gross Exports of Cut and Polished diamonds during 2014-2015 at US\$23160.18 million shows a decline of 5.46\% compared to US\$ 24498.48 million during 2013-14. Gold Jewellery export worth US\$ 8557.26 million during 2015-16 showed a decline of $13.59 \%$ when compared to US\$ 9903.61 million during 2014-15. Gold Jewellery studded with diamonds at US\$ 4266.07 million constitute 50\% of total export of gold jewellery at US\$ 8557.26 million during 2015-16 [24]. Gold medallions \& Coins exports at US\$ 2836.78 million during 2014-15 shows a decline of 7.58\% when compared with 2013-14.

Coloured gemstones exports at US\$ 453.25 million during 2014- 15 shows a decline of $29.89 \%$ compared to US\$ 646.52 million during 2013-2014. Silver Jewellery exports at US\$2052.10 million during 2014-15 shows a growth of $39.12 \%$ in comparison with exports of 2013-14. From India, gems and jewellery are mainly exported to UAE, Hong Kong, USA, Thailand, UK, Africa, Israel, Belgium and Switzerland etc. U.A.E remained the single largest importer during 2015-2016 accounting for around 32\% of the total gems and jewellery followed by Hong Kong, USA, Belgium and Israel etc. [24].

\subsection{Unorganised Sector}

\section{Problems Faced By Gems And Jewellery Exporters}

India's gems and jewellery industry is vastly unorganized and $90 \%$ of the players having family owned businesses. However, the organised sector is also increasing. Even though the growth is slow, in future it is likely to cover a major share of the market due to the change in lifestyle and preference of customer [26]. The unorganized sector hampers the ability of Indian gems and jewellery industry to emerge as a world- class supplier. According to a FICCI study, the gold processing industry have around 15,000 players, with only 80 units having revenues over US \$ 5 million. India is also home to around 450,000 goldsmiths, over 100,000 gold jewellers along with about 6,000 diamond-processing players and 8,000 diamond jewellers [27].

\subsection{Dependency on Imports}

The gems and jewellery industry mainly depends on the supply of raw materials. In India 90 per cent of raw material is imported and its supply is limited. The raw material is processed to finish products to sale in international market. Rough diamonds as raw material accounts for more than 50 per cent of imports of raw material [17]. During the year 2009-10 import of total rough diamonds was Rs.316 billion. India imports rough diamonds mainly from Belgium, the UK, Israel and the UAE etc. while gold jewellery is imported from Switzerland, South Africa, the UAE and Australia etc. Raw pearls and, precious and semi-precious stones are imported from Belgium, the UK and Hong Kong etc. Europe has become the largest importing destination of raw material for Indian gems and jewellery industry [28]. 
Exporters depends completely on imported raw material, hence more export should lead to more import. But the fact which causes worry is that excess imported raw material, when exported gives fewer earnings in foreign exchange. Another concern is to make the deal for a fair price of raw material imported as it directly affects the cost of production and due to which cost of exports does not let us stand in competitive international market [29].

\subsection{Changing Trend}

Global marketing requires a changing fashion of gems and jewellery particularly in the context of very high prices of diamond, gold and silver. Exporters not having enough design development centres and to innovate latest designs to match with the changing trend of foreign buyers [30]. Manufacturers manufacture specific type of gems and jewellery products according to the market demand. But due to change of trend, demand of that type of products start decreasing and eventually it finishes. This situation blocks the manufacturer's capital and the huge stock is collected. The producers give the stock to the brokers for selling. The consumer reduces the cost of production to half in this condition: the sellers don't sell their items under the cost of product [28].

\subsection{Human resource problems}

Employees are significant part of any industry. The labour force in Indian gems and jewellery sector is less productive as compared to China, Thailand, the USA, the UK, Sri Lanka and Israel. Non-availability of skilled workers is often cited as one of the major reasons for the inability of the players in this industry to scale up their operations. Supply of craftsmen / artisans that come through generations need to be complemented by fresh talents, trained in a professional manner, to have access to wider talent pool [27]. The industry has seen an increasing shift to wax techniques form metal. Metal working mould making and setting is far more difficult than working on wax in terms of skill requirement and time required. However, the exporters is facing a paucity in the availability of workers skilled in metal work (NSDC report). The industry's on-the-job training model leads to longer training time and creates gaps in availability of industry best practices and standardization, mainly for the fragmented part of the industry [29].

\subsection{Rise in price}

The prices of gold and silver, have been witnessing sudden increase, since the last few years, which has been changing the buying pattern of consumers. During the period December 2008 to December 2009, the price of gold per ten grams, has increased from Rs.13,445 to Rs.16,870, an increase of 26 per cent (Bose, 2011). Even though the price of silver had shown a decline after February 2009, it again started rising after April 2009. From Rs.17,847 per $\mathrm{kg}$ in December 2008, the silver price increased to Rs.27,430 per $\mathrm{kg}$ in December 2009. In December 2013 gold per ten gram Rs.30221, and Silver was Rs.44223 per kg. [31].

Indian gems and jewellery $(\mathrm{G} \& \mathrm{~J})$ sector has been primarily impacted by the imposition of various government regulations, rising gold prices, rupee depreciation and sluggish GDP growth globally and in India. With rising and volatile gold prices, the demand for gold jewellery and gold bars and coins tends to decline. In order to curtail the rising $\mathrm{CAD}$, a slew of measures have been taken by the government to curb gold imports and the rising $\mathrm{CAD}$. These regulations negatively impact the industry by increasing the working capital requirements, constraining the gold supply in the short term, hike in gold prices and reducing investment demand for gold. Also, the slowdown in the global economic growth mainly in US and Europe would to a certain extent impact the growth of emerging nations like China and India [32].

\subsection{Competition from China and other countries}

Although India currently enjoys dominance in the world's cut and polished diamond market, China may emerge as a rival in the long-term, mainly because of the availability of cheap labour, growing domestic demand, and also the improvement in the quality of workmanship in the country. It may be added that increasing number of diamond processors are setting up their facilities in China due to these reasons. Also, there has been growing pressure in major diamond producing countries in Africa, like Botswana, Namibia and South Africa, to gain further economic benefits from diamond value chain, seeking investments in cutting and polishing industry. Such developments may affect the prospects of India [27].

An increasing number of diamond processors from Israel and Belgium, and even India, are setting up facilities in China, for reasons like the cheap and disciplined labour force, significant increase in potential consumers in the high- income segment within the country and the steadily improving quality of Chinese workmanship. Technology is the area where the Indian industry faces a long term threat from China (NSDC report). However, China with its modern and automatic factories is today in a similar position to manufacture jewellery at competitive prices [5]. 


\subsection{Financial problems}

The exporters is facing challenges in availability of low cost financing. The short term bank credits like cash credits, letter of credit with interests ranging from 10 to $15 \%$ are very costly to exporters as the raw material costs are very high, lending to financing challenges for jewellers [33]. In gems and jewellery industry since the most of the stones dealt with are expensive, hence the exporters need more finance for investment. Other problems faced by gems and jewellery exporters while sourcing their capital are as under:

- High rate of interest being charged by the banks on export credit.

- Lack of dollar credit for sourcing of rough diamond.

- Less sanction on extension of credit limits of gems and jewellery exporters.

- Existence of partiality in rating of gems and jewellery firms by credit rating agencies

- In addition to this, formalities of the financial organization are so much that it is highly time consuming process [34].

\subsection{Transportation}

Transportation is the nerve knot of gems and jewellery industry of India. Exporters in gems and jewellery industry fall a victim to the problem of not being able to fulfil the demand of products. They also fill the absence of any professional organization or government counter, so that they may purchase raw material of gems and jewellery according to their necessities. Export is an essential hardship [29]. The clearance of parcel from custom and other formalities take a lot of time and after the dispatch of parcel it reaches in the foreign country within 5-6 days. To overcome this problem, exporters dispatch their parcel from Delhi and the parcel reaches the country concerned within one day. But the parcel of such a precious thing is not safe [34].

\subsection{Research and Product Development}

Another major challenge faced by the exporters is the low level of research and development (R\&D) intensity and facilities for undertaking research and product development. Proper R\&D solutions would help in improving product quality, reducing wastage, introducing new designs and concepts, and innovation in supply chain management and marketing. The gap between hi-end machines and unskilled labour can also be reduced with innovative R\&D solutions [35].

\section{Conclusion and Recommendations}

Indians have been using jewellery for adornment since centuries. The significance of jewellery in the country is evident from the fact that on many auspicious occasions, jewellery forms a part of gifts. Jewellery has not only been considered for the purpose of adoration, but also as a security in times of contingency. The gems and jewellery products export fetch several crores of foreign currency to our country and provides an employment opportunity to our people. The production of the gems and jewellery products must be enhanced to increase the exports into global level. The size of the Indian jewellery market is the largest in the world, second only to the US market, followed by China, Japan and Italy. The huge growth of the Indian gems and jewellery industry has led augmentation of many new branded jewellery shops in various metros of this country. Brands such as, Damas Jewellery, Reliance Retail, Swarovski, and Joy Alukkas are either opening or have already opened their new branches. But still this sector is unorganised, $80 \%$ jewellery business done by family jewellers. To improve the exports of gems and jewellery products government should take initiatives to maximise the export of imported raw material.

To fasten up with the new trends in global market, product planning and development is highly recommended. It is necessary to establish design development centres to bring new futuristic designs in order to compete internationally. The price of gold, silver and diamonds have seen sudden increase in last few years which has changed the buying pattern of consumers. Consequently export of gems and jewellery has seen a decline which could be favourable if the production is reasonable, competitive and meeting customer expectations. The other major problem faced by exporters is competition with other countries. India is facing Competition with other countries mainly with China, Hong-Kong. China has strengths like infrastructure, cheap economic labour, and a welcoming government. It also offers attractive labour union terms and export-friendly policies. Indian exporters, at times find it very difficult to cope with other countries in terms of cost, quality, standards, popularity, etc. India presently enjoys dominance in the world's cut and polished diamonds market, China may emerge as a major rival. Technology is another aspect where Indian gems and jewellery industry faces a major threat from China. Also, there has been a threat to cutting and polishing industry of India, from the growing investments of African countries to set up cutting and polishing facilities locally in their country. Italy is our main competitor in the field of gold jewellery and studded jewellery. The growth of exporters depends on the technical advancements, and maintenance of goodwill to beat the competitions, which is extruding day by day. 
In gems and jewellery industry, since most of the stones dealt with, are expensive, hence the exporters need more finance for investment. Another problem faced by exporters is sourcing capital. The credit development by the banks to the exporters is very low and declines year by year. Government should take initiatives to provide sufficient credit to this industry for promoting the exports and helping in the development of the economy. The exporters are facing various complications due to their traditional approaches thus there is urgency of acquiring modern techniques in addition to advanced tools and equipment acceptable by the workers. As the sector is highly labour-intensive, its dependency on craftsmanship is very high. For instance, the cutting and polishing of diamonds and coloured gems, which are soft stones, requires immense care on the part of the labourer. Training is important within any organization as it directly relates to productivity. There are very less institute to provide training in all aspects of manufacturing and design. It is necessary that government take initiatives for the development of workers. Association like (ITPO), IIFT and GJEPC should refine their operation and contribute towards export promotion of gems and jewellery. It is sure that future of the gems and jewellery industry is bright but it is necessary to take several measures at firm-level, industry-level, and Government- level, to strengthen the position of India in global market.

\section{References}

[1]. ASSOCHAM India 2015- http://tari.co.in/wp-content/uploads/2015/11/The-Gems-Jewellery-Industry-For-website.pdf

[2]. FICCI, 2013- http://ficci.in/spdocument/20332/india-jewellery-review-2013.pdf

[3]. The guardian (2012), https://www.theguardian.com/world/2012/feb/20/china-india-biggest-gold-market

[4]. Gajigo O., Mutambatsere E. and Ndiaye G., "Gold Mining in Africa: Maximizing Economic Returns for Countries", African development bank group, Working paper No. 147, 2012, 1-10.

[5]. ICRA, 2006- http://www.forcesofindia.com/resources/presentations/Gems\&Jewellery-200607.pdf

[6]. Sharma R. and Sharma P., "Exploring the role of gems and jewellery industry on Indian exports", Asian academic research journal of social science \& humanities, 1(16), 2013, 209-215.

[7]. HKTDC research, 2017.- http://m.hktdc.com/business-news/article/Hong-Kong-Industry-Profiles/Jewellery-Industry-in-HongKong/hkip/en/1/1X000000/1X001DFI.htm

[8]. NSDC report- http://www.nsdcindia.org/sites/default/files/files/Gems-Jewellery-2009.pdf

[9]. Singaravelu K. and Subhashini K., " Economic analysis of Indian gems and jewellery industry without shopping experience of consumers", International Journal of Business and Administration Research Review, 2(16), 2016, 103-107.

[10]. GJSCI, 2014- http://www.gjsci.org/reports/IMaCS\%20Gems\%20and\%20Jewellery\%20Industry\%20Report-May2014-2\%20\%20Copy.pdf

[11]. Das P. and Borthakur S., "Export of Gems and Jewellery: The Indian Perspective", Indian journal of applied research, 3(4), 2013, 211-213.

[12]. Kumar B. and Punithavathi S., "A study on country wise exports of gems and jewellery from India", International journal of marketing management, 2(2), 2014, 119-131.

[13]. Saha S., "Wage Dispersion and the Loss-Wage Model: The Case of Bowbazar Gems and Jewellery Industry in Kolkata", The International Journal Of Humanities \& Social Studies, 3(7), 2015, 172-178.

[14]. IBEF Report 2017- https://www.ibef.org/industry/gems-jewellery-india.aspx

[15]. Das P. and Borthakur S., "Gems and jewellery: The dark horse of Indian exports", International journal of research in commerce, economics \& management, 3(4), 2013, 76-79.

[16]. SME Times 2012- http://www.smetimes.in/smetimes/in-depth/2012/Aug/28/india-s-gems-jewellery-industry-a-dazzling-successstory.html\#sthash.V4RRguyc.dpuf

[17]. Parasakthi D. and Dhanalakshmi P," A Study on Problems Faced By Gem and Jewellery Exports with Special Reference to Coimbatore City", International Journal of Emerging Research in Management \&Technology, 4(7), 2015, 251-254

[18]. NSDC, 2013- http://www.nsdcindia.org/sites/default/files/files/Gems-Jewellery.pdf

[19]. FICCI- http://www.ficci.com/sector-overview.asp?secid=17

[20]. Dahat S., "Gems \& Jewelery - A New Opportunity", Sansmaran, 2, 2012, 3-6.

[21]. ONCRA 2013 - http://www.onicra.com/images/pdf/ReportGemsandJewellery2911.pdf

[22]. GJEPC Annaul report (2012-13)- https://gjepc.org/

[23]. Business Standrad- http://www.business-standard.com/article/economy-policy/gems-and-jewellery- imports-in-india-raise-by-8114030600412_1.html

[24]. GJEPC Annual report (2015-16)- https://gjepc.org/emailer_gjepc/mailer/agm/ar.pdf

[25]. GJEPC Annual report (2014-15)- https://gjepc.org/pdf/DigitalVersion_AnnualReport2014-15_V1.pdf

[26]. Arora N., Indian diamond industry problems and prospects, Himalaya publishing house, 2014, 17-20.

[27]. Bose C., "Challenges and strategies for development of Indian gems and jewelleries", International journal of marketing and management research, 2(3), 2011, 96-105

[28]. Kumar N., "Problems and prospects of India's export of gems and jewellery, Kurukshetra university, 2013, 10-50.

[29]. S. Madhavi and Rama Devi T., "Problems of Indian jewellery industry", International Journal of Management Research \& Review, 5(8), 2015, 623-628.

[30]. Lamba S. and Saini N., "Prospects of Gems and Jewellery Export in India", International Journal of Recent Research in Commerce Economics and Management, 2(1), 2015, 126-132.

[31]. http://www.marketonmobile.com/Silver-Price-2013/December

[32]. CARE research- https://researchreports.careratings.com/files/brochure/gemsjewell-50bba19a46b4ec6.pdf

[33]. Elizabath N., " Challenges faced by gold economy in India", International journal of economics and business review, 2(10), 2014, 77-84.

[34]. Kumar N., "Indian gems and jewellery industry: problems and future prospects", Indian journal of applied research, 3(10), 2013, 14.

[35]. Prahalathan S. and Vijay R., "Indian gems and jewellery: A sector study", Import export bank of India, Occasional paper No.138, $2010,60-95$. 


\section{Import and Export of gems and jewellery}

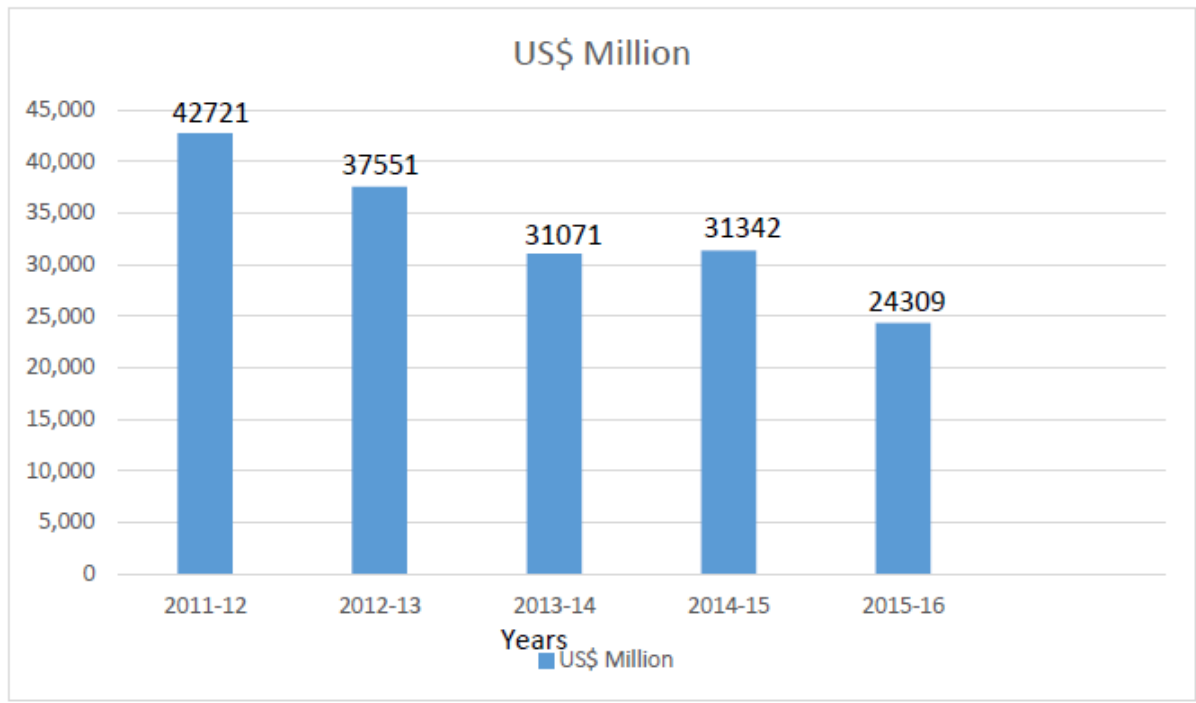

Figure 1: Import of raw material for gems and jewellery

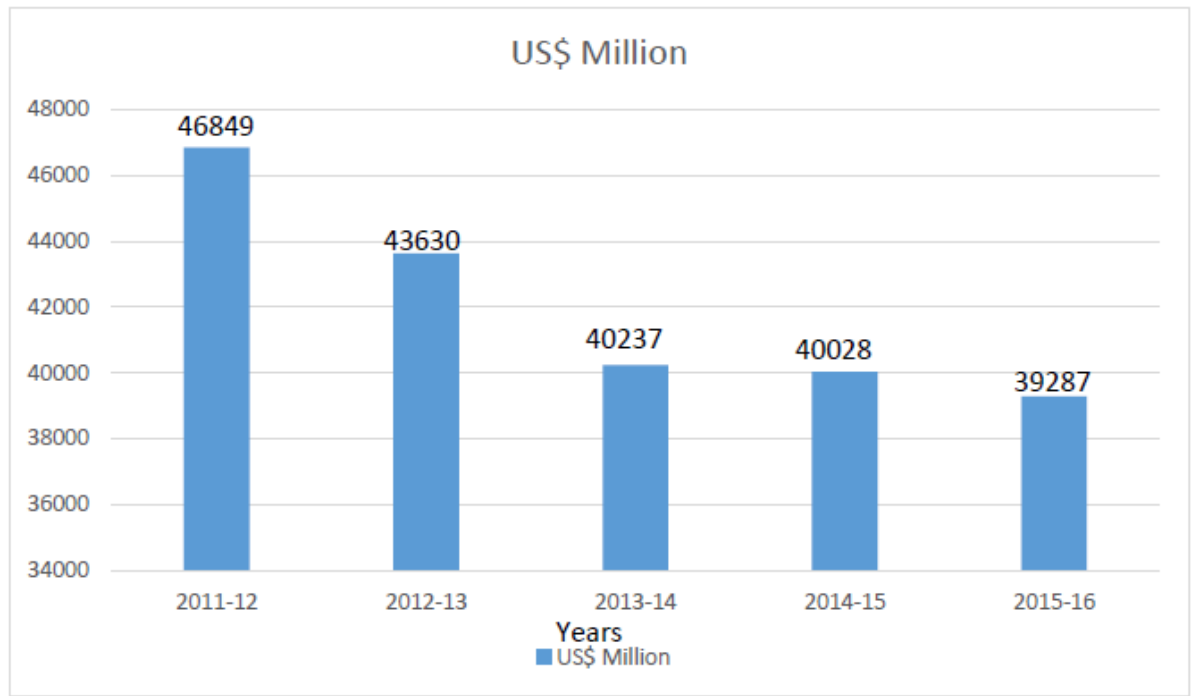

Figure 2: Export of gems and jewellery 